Oana M. Dumitrascu, MD, MS

Andrew McKeon, MD

Leslie Zuniga, MD

Marie F. Grill, MD

Brent P. Goodman, MD

Neurol Neuroimmunol

Neuroinflamm

2017;4:e376; doi: 10.1212/

NXI.0000000000000376

\section{OPSOCLONUS-MYOCLONUS SYNDROME DURING RITUXIMAB TREATMENT FOR AUTOIMMUNE AUTONOMIC GANGLIONOPATHY \\ OPEN}

Adult-onset opsoclonus-myoclonus syndrome (OMS) is an autoimmune disorder with paraneoplastic, parainfectious, or idiopathic etiologies. ${ }^{1}$ Nonparaneoplastic cases are generally immunotherapy responsive. ${ }^{1}$ Although previously described accompanying encephalopathy in NMDA receptor (NMDA-R) encephalitis, ${ }^{2}$ OMS occurring as an isolated CNS finding in an NMDA-R antibody-positive patient appears to be unusual, particularly among patients with preexisting $\alpha 3 \mathrm{AChR}$ antibody-associated dysautonomia. We describe a patient in whom an autoimmune CNS disorder isolated to OMS arose in the context of rituximab treatment administered for refractory autoimmune dysautonomia.

A 61-year-old woman with a history of prior gastric sleeve procedure to treat morbid obesity presented with profound orthostatic hypotension and recurrent syncopal episodes. She was diagnosed with severe global autonomic failure involving postganglionic sympathetic sudomotor, cardiovagal, and cardiovascular adrenergic systems. The serum $\alpha 3 \mathrm{AChR}$ antibody was positive (value, $1.30 \mathrm{nmol} / \mathrm{L}$; normal, $\leq 0.02$ ). CSF studies were not pursued at that time. IV immunoglobulin, mycophenolate mofetil, plasma exchange, and symptomatic therapy provided modest or transient benefit. Because of suboptimal treatment response, rituximab was initiated $(1,000 \mathrm{mg}, 2$ infusions, 2 weeks apart, with diphenhydramine and acetaminophen as premedication). Within 2 weeks of the first infusion, the patient developed progressive vertigo, oscillopsia, gait instability, and diffuse body tremulousness. Symptoms worsened after the second rituximab infusion. Despite this, autonomic symptomatology had improved, and no behavioral or mood changes were encountered. Neurologic examination 1.5 weeks after the second rituximab infusion revealed opsoclonus, myoclonic limb movements, and truncal ataxia. Contrast-enhanced brain MRI was unrevealing. Chest, abdomen and pelvis CT, mammography, and whole-body PET/CT did not identify underlying malignancy. CSF evaluation revealed 119 nucleated cells/ $\mathrm{L}$ (normal less than 5)
Clinical/Scientific Notes

with lymphocytic predominance (91\%), absent red blood cells, normal glucose $(55 \mathrm{mg} / \mathrm{dL})$, and mildly elevated protein (63 mg/dL, normal range 14-45). There were no supernumerary CSF oligoclonal bands. Flow cytometry, cytology, and detailed serum and CSF infectious studies for fungal, bacterial, mycobacterial, spirochetes, and viral pathogens were negative. Comprehensive serum and CSF autoantibody testing demonstrated NMDA-R antibody in the CSF only (at a low titer by cell-based assay [1:2]; indirect immunofluorescence assay using a composite of mouse tissues, including brain, was negative $[<1: 120]$ ), and $\alpha 3 \mathrm{AChR}$ antibody in serum (titer, $0.69 \mathrm{nmol} / \mathrm{L}$ ). OMS improved significantly within 1 week of initiation of IV methylprednisolone treatment ( $1 \mathrm{~g}$ daily for 5 days). The patient was discharged to a skilled nursing facility with plan for a 12 week course of pulse methylprednisolone: $1 \mathrm{~g}$ of methylprednisolone once weekly for 5 more weeks, followed by once every other week dosing for 6 weeks.

Despite improved recognition of OMS in adults and advancements in antibody diagnostics, the pathogenesis of many cases remains incompletely understood. ${ }^{1}$ Unusual aspects of this report include NMDA-R autoimmunity occurring in the context of OMS without NMDA-R-typical encephalopathy or neuropsychiatric symptoms and the occurrence of this clinical-serological constellation in the context of rituximab treatment of another autoimmune disorder. OMS has been previously reported in patients with NMDA-R autoimmunity, where the clinical course was otherwise typical for that disorder, and encephalitic symptoms were prominent. ${ }^{2}$

The mechanism by which the patient paradoxically developed OMS after the initiation of rituximab is unclear. Rituximab appears to be an effective off-label therapy in many cases for autoimmune encephalitis. $^{3}$ In neuromyelitis optica, relapses of optic neuritis and transverse myelitis have been reported to occur within 2 weeks of rituximab treatment. ${ }^{4}$ It has been hypothesized that rituximabinduced B-lymphocyte depletion leads to transient increases in serum B-cell activating factor, which in turn induces a paradoxical upregulation of aquaporin4 autoimmunity. ${ }^{5}$ Similarly, paradoxical and abrupt elevations in serum IgM levels after rituximab therapy 
initiation have been described in Waldenstrom macroglobulinemia. ${ }^{6}$ Biological factors specific to rituximab in contrast to other novel anti-CD20 monoclonal antibodies ${ }^{7}$ may play a role in pathogenesis, such as differences in core epitope sequences and binding conformations, although precise mechanisms have yet to be elucidated. It is possible that NMDA-R autoimmunity was triggered by a similar mechanism in our patient, although $\alpha 3 \mathrm{AChR}$ antibody titer did not rise and autonomic symptomatology remained stable. Coadministration of methylprednisolone will be considered for future rituximab treatment epochs in our patient. Similarly, coadministration of "prophylactic" corticosteroids with initial rituximab infusions might be warranted in the management of other autoimmune disorders.

Previous studies have demonstrated that rituximab may paradoxically promote autoantibody production through a poorly understood mechanism. ${ }^{5}$ The risk of new or recurrent immune-mediated neurologic disorders arising as a result of rituximab therapy mandates close posttreatment monitoring, particularly at the present time when the use of B-cell depletion therapy for the treatment of autoimmune neurologic diseases is increasing.

From the Department of Neurology (O.M.D., L.Z., M.F.G., B.P.G.), Mayo Clinic, Phoenix, AZ; and Department of Neurology (A.M.), Mayo Clinic, Rochester, MN.

Author contributions: Oana M. Dumitrascu: drafting/revising of the manuscript, study concept or design, analysis or interpretation of the data, accepts responsibility for conduct of research and will give final approval, acquisition of data, and study supervision. Andrew McKeon: drafting/revising of the manuscript, analysis or interpretation of the data, and acquisition of data. Leslie Zuniga: drafting/ revising of the manuscript. Marie F. Grill: drafting/revising of the manuscript and analysis or interpretation of the data. Brent P. Goodman: drafting/revising of the manuscript, study concept or design, and analysis or interpretation of the data.

Study funding: No targeted funding reported.
Disclosure: O.M. Dumitrascu reports no disclosures. A. McKeon has patents pending for GFAP and MAP1B as markers of neurological autoimmunity and paraneoplastic disorders; consulted for Grifols, MedImmune, and Euroimmun; and received research support from MedImmune. L. Zuniga and M.F. Gill report no disclosures. B.P. Goodman consulted for Lundbeck. Go to Neurology.org/nn for full disclosure forms. The Article Processing Charge was funded by the Mayo Clinic.

This is an open access article distributed under the terms of the Creative Commons Attribution-NonCommercial-NoDerivatives License 4.0 (CC BY-NC-ND), which permits downloading and sharing the work provided it is properly cited. The work cannot be changed in any way or used commercially without permission from the journal.

Received February 3, 2017. Accepted in final form March 23, 2017.

Correspondence to Dr.Dumitrascu: Dumitrascu.oana@mayo.edu

1. Klaas JP, Ahlskog JE, Pittock SJ, et al. Adult-onset opsoclonus-myoclonus syndrome. Arch Neurol 2012;69: 1598-1607.

2. Armangue T, Titulaer MJ, Malaga I, et al. Pediatric anti-Nmethyl-D-aspartate receptor encephalitis-clinical analysis and novel findings in a series of 20 patients. J Pediatr 2013;162:850-856.e2.

3. Titulaer MJ, McCracken L, Gabilondo I, et al. Treatment and prognostic factors for long-term outcome in patients with anti-NMDA receptor encephalitis: an observational cohort study. Lancet Neurol 2013;12:157-165.

4. Lindsey JW, Meulmester KM, Brod SA, Nelson F, Wolinsky JS. Variable results after rituximab in neuromyelitis optica. J Neurol Sci 2012;317:103-105.

5. Nakashima I, Takahashi T, Cree BA, et al. Transient increases in anti-aquaporin- 4 antibody titers following rituximab treatment in neuromyelitis optica, in association with elevated serum BAFF levels. J Clin Neurosci 2011; 18:997-998.

6. Treon SP, Branagan AR, Hunter Z, Santos D, Tournhilac $\mathrm{O}$, Anderson KC. Paradoxical increases in serum IgM and viscosity levels following rituximab in Waldenstrom's macroglobulinemia. Ann Oncol 2004;15:1481-1483.

7. Klein C, Lammens A, Schafer W, et al. Epitope interactions of monoclonal antibodies targeting CD20 and their relationship to functional properties. MAbs 2013;5:22-33. 


\section{Neurology \\ Neuroimmunology \& Neuroinflammation}

\section{Opsoclonus-myoclonus syndrome during rituximab treatment for autoimmune autonomic ganglionopathy}

Oana M. Dumitrascu, Andrew McKeon, Leslie Zuniga, et al.

Neurol Neuroimmunol Neuroinflamm 2017;4;

DOI 10.1212/NXI.0000000000000376

This information is current as of June 28, 2017

\section{Updated Information \& \\ Services}

References

Subspecialty Collections

Permissions \& Licensing

Reprints including high resolution figures, can be found at:

http://nn.neurology.org/content/4/5/e376.full.html

This article cites 7 articles, 0 of which you can access for free at: http://nn.neurology.org/content/4/5/e376.full.html\#\#ref-list-1

This article, along with others on similar topics, appears in the following collection(s):

All Neuro-ophthalmology

http://nn.neurology.org//cgi/collection/all_neuroophthalmology

Autoimmune diseases

http://nn.neurology.org//cgi/collection/autoimmune_diseases

Autonomic diseases

http://nn.neurology.org//cgi/collection/autonomic_diseases

Information about reproducing this article in parts (figures,tables) or in its entirety can be found online at:

http://nn.neurology.org/misc/about.xhtml\#permissions

Information about ordering reprints can be found online:

http://nn.neurology.org/misc/addir.xhtml\#reprintsus

Neurol Neuroimmunol Neuroinflamm is an official journal of the American Academy of Neurology.

Published since April 2014, it is an open-access, online-only, continuous publication journal. Copyright

Copyright $\odot 2017$ The Author(s). Published by Wolters Kluwer Health, Inc. on behalf of the American

Academy of Neurology.. All rights reserved. Online ISSN: 2332-7812.

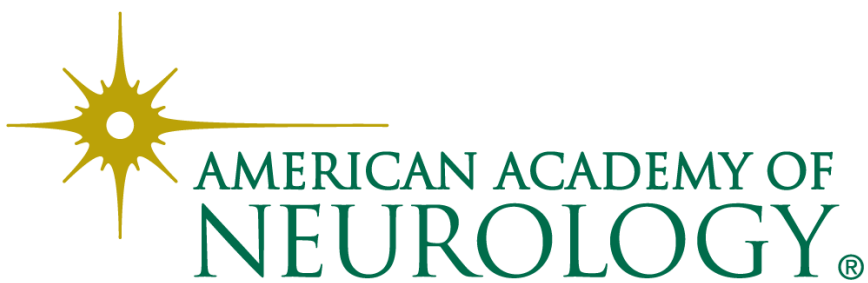

